Relations industrielles

Industrial Relations

\title{
Toward a Union of Families
}

Volume 6, numéro 3, juin 1951

URI : https://id.erudit.org/iderudit/1023226ar

DOI : https://doi.org/10.7202/1023226ar

Aller au sommaire du numéro

Éditeur(s)

Département des relations industrielles de l’Université Laval

\section{ISSN}

0034-379X (imprimé)

1703-8138 (numérique)

Découvrir la revue

Citer cet article

(1951). Toward a Union of Families. Relations industrielles / Industrial Relations, 6(3), 89-91. https://doi.org/10.7202/1023226ar

Tous droits réservés (C Département des relations industrielles de l’Université Laval, 1951
Ce document est protégé par la loi sur le droit d'auteur. L'utilisation des services d'Érudit (y compris la reproduction) est assujettie à sa politique d'utilisation que vous pouvez consulter en ligne.

https://apropos.erudit.org/fr/usagers/politique-dutilisation/ 
primarily with the problem of unemployment which in its threatening and permanent menace "risks to starve thousands of men, the immense multitude of unfortunates. .." "This problem of periodic unemployment," says Mr. Bayart "is the crucial problem of capitalism, and more exactly of an economic system founded on the dynamic development of technical progress, which by the movement it imparts to the economic activity, necessarily initiates, in its forward progress, the variations, fluctuations and depressions, cyclical or not." Here is the summary of the Papal conception in this speech of June 3rd as presented by Mr. Bavart :

"The rejection of the "mechanism of social organizations in contradiction with the order established by God," i.e. the integral planning of the soviet system;

The rejection of a pure and simple return to a liberalism condemned by the Church and exceeded by the facts, which, to re-establish a normal economy, would depend only on the mechanism of the laws of the market;

The warning against the deformation of social security by a socialistic conception which would place « trust in an all-providing state (un étatprovidence) charged with providing for each of its subjects, and in every circumstance of life, the right to advance claims which basically cannot be satisfied 》;

The warning against certain conceptions of full employment realized by too artificial formalism;
The primordial necessity, in order to realize this policy of full employment and the first of social securities: that of work, to organize, at the very source of the economy, and in avoiding the excesses of a production without bounds, a sane and normal production, " wisely measured according to the needs and to the dignity of men " and arranged around the organic unit basis of society, which is the Family ;

The maintenance, at the basis of the economy, of the private enterprise, with all the concessions corresponding to its social character, but in maintaining nevertheless its private character and in leaving to management the personal responsibility and the control of economic decisions and in safeguarding as much as possible against the double danger of anonymous capitalism and socialization, the soundest portion of the economy - individual and family exploitations ;

The positive declaration, repeated once again, of the primordial necescity of professional organization."

This is the new direction that the Holy Father points out to world economy. $\mathrm{He}$ asks now that "theorists and men of action . . . concentrate their attention upon, making it the focal point of their study . . . on the imminent and permanent threat of unemployment, the most important and urgent problem, that which weighs like a nightmare precisely on these old industrial countries ...."

\section{Toward a Union of Families}

Last April 23rd and 24th, the Department of Industrial Relations of the Faculty of Social Sciences of Laval welcomed in the vast Ballroom of the Chateau Frontenac, nearly five hundred delegates who came from all corners of the Province and from many walks of life: employers, workers, personnel managers, foremen, officers of employers' and workers' associations, representatives of parity committees, moral advisors, government labour officials, representatives of social groups, etc.

For two days, the delegates studied, with the proper attention and 
under the enlightened direction of well-informed lecturers and committees formed of practical experts, the theoretical aspect of social security in relation to the workman's family, as well as its principal methods of application.

The first two meetings were reserved for the study of the principles of security and particularly of full employment as a fundamental element of the security of the workman's family. Much interest and continued attention were also shown to the examination of the practical measures planned or already being realized in our country.

The guest speaker at the closing banquet of the Convention, the Reverend Father Gonzalve Poulin, O.F. M., Director of Studies at the Faculty of Social Sciences and Director of the School of Social Work of Laval, wished to extend the examination of the problem beyond that of the economic security of the workman's family. After having analyzed the two factors which throw the family off its balance, improvised urbanization and the change in the social function of private property, the speaker outlined the possible ways to a solution in a better organization of the industrial, social and family spheres. As far as the conditions of family stability are concerned, the speaker reduced them to the following three : making the place of work more human, the promotion of social security measures and the organization of the family in the social-political scheme. This last condition presented in a new perspective deserved particular notice and the following extract from this masterly speech should be drawn to the attention of our readers :

"It is perhaps in the social-political sphere that it is most difficult for the workman's family to take root. Because the organization of capital and labour only influences political life in the direction of economic interests, this results in a democracy of individualistic character, and of which the laws apparently social, such as security measures, are made for the individual, rather than for the family group. If the family, by organization, became a social force, it would have its political and social rights recognized, would stress the communal character of society and would make easier the peaceful integration of the workman's family in the national community.

This would result in a stronger social tie between the various groups in a nation, and, in those responsible for the State, a greater consideration for the family reality. It is not so long ago that the family formed the centre of the political, economic and social life!

A union of families would ensure a better education of its citizens by a more normal play of social community of interests and the spread of such institutions of family mutual aid as mutual societies, cooperatives, family services etc. The public morality and social customs would receive an enlightened control. The workman's family, joined with the families of other social classes, would not have the impression of being banned from modern society. It would bring its active participation to the common good of the City in an atmosphere of confidence indispensable to its development and promotion.

If the union of families, in addition to such social functions, assumed a rôle of political representation towards the public authorities; if by means of a Superior Council of Family Welfare, it would advise the State in its social legislation, limiting the executive functions of the latter which interferes more and more in the private life of its citizens, to the detriment of its suppletory and regulating responsibilities; if it had a family code accepted and thus 
corrected the too-individualistic character of modern law, perhaps we would see a movement of decentralization gain all the spheres of industrial and social life. The organic function played by the family of yesterday in rural civilization would again be revived, but under forms adapted to industrial civilization.

The initiative of organizing family forces belongs evidently to the family itself; we believe that the States, however, in the common interest, should stimulate the birth and development of this organization by assuring it a representative place in its public commissions and organizations."

In conclusion, the eminent speaker appropriately remarked that "any economic-social restoration of the workman's family is doomed to failure unless it is accompanied by a renewal of Christian life. "If the work of restoration", write the Bishops of the Province of Quebec, "is accomplished in the light of the eternal verities of justice and charity, the parties in presence will ask God and religion the clear view of their respective functions in society and their necessary cooperation to the common good as well as the supernatural force to do their duty. Instead of trying to maintain positions acquired or attempt to merely upset established order, they would try sincerely to keep that which is legitimate and to replace that which does not merit keeping. And thus, religion, by its teachings on man, his family, his leisure and his work, by the grace indispensable to any work of merit, will be the basis of a Christian restoration of the life of the worker."

This Convention, as the delegates themselves acknowledge, was a magnificent occasion for exchange of viewpoints and for useful contacts. But in addition, on the occasion of the sixtieth anniversary of the publication of the Encyclical "Rerum Novarum", the Department of Industrial Relations felt it should touch more closely the problems of the worker, to examine the underlying causes in order to discover, in the light of the social doctrine of the Church, the possible solutions. It did not wish to avoid its responsibilities, even if it meant limiting itself to only a few essential points. By so doing, it feels it has made an attempt to promote in its sphere the peace and social justice to which all aspire ardently.

N.B.-The works presented on the occasion of the Sixth Industrial Relations Convention will be bound in a report which will be put on sale shortly at the Department of Industrial Relations, 2. rue de l'Université, Québec.
Hate never builds anything; it can only, blast. Every beautiful thing has been loved into being.
Joseph Fort Newton

If we are to preserve civilization, we must remain civilized.

Louis St. Laurent 